\title{
Mucus: aiding elasmobranch conservation through non-invasive genetic sampling
}

\author{
Lilian Lieber ${ }^{1, \dagger}$, Simon Berrow ${ }^{2,3, \dagger}$, Emmett Johnston ${ }^{2}$, Graham Hall ${ }^{4}$, Jackie Hall ${ }^{4}$, \\ Chrysoula Gubili ${ }^{1,8}$, David W. Sims ${ }^{5,6,7}$, Catherine S. Jones ${ }^{1, *}$, Leslie R. Noble ${ }^{1, *, *}$ \\ ${ }^{1}$ Institute of Biological and Environmental Sciences, School of Biological Sciences, University of Aberdeen, \\ Aberdeen AB24 2TZ, Scotland \\ ${ }^{2}$ Irish Basking Shark Project, Buncrana, Co. Donegal, Ireland \\ ${ }^{3}$ Marine and Freshwater Research Centre, Galway-Mayo Institute of Technology, Dublin Road, Galway, Ireland \\ ${ }^{4}$ Manx Basking Shark Watch, Manx Wildlife Trust, Isle of Man IM4 3AE, UK \\ ${ }^{5}$ Marine Biological Association of the United Kingdom, The Laboratory, Citadel Hill, Plymouth, Devon PL1 2PB, UK \\ ${ }^{6}$ Ocean and Earth Science, National Oceanography Centre Southampton, University of Southampton, Waterfront Campus, \\ Southampton SO14 3ZH, UK \\ ${ }^{7}$ Centre for Biological Sciences, Building 85, University of Southampton, Highfield Campus, Southampton SO17 1BJ, UK
}

${ }^{8}$ Present address: Faculty of Environmental Design, University of Calgary, 2500 University Drive NW, Alberta T2N 1N4, Canada

\begin{abstract}
Large-scale genetic sampling by non-invasive methods is of vital importance for the conservation of vulnerable or elusive species. In the marine environment, non-invasive genetic sampling can provide a powerful alternative to conventional biopsies. We designed and implemented mucus swabbing for a free-ranging elasmobranch, thereby demonstrating the utility of this method in the field. We report the first attempt at mucus collection from 30 plankton-feeding basking sharks Cetorhinus maximus from 3 spatially distinct 'hotspots' in Irish waters. C. maximus DNA was successfully extracted and verified using DNA barcoding of the mitochondrial DNA cytochrome $c$ oxidase 1 gene (99\% sequence similarity) and basking shark species-specific multiplex PCRs derived from the nuclear ribosomal internal transcribed spacer 2 locus. Mitochondrial control region sequencing (1086 bp) showed that Irish samples were dominated by 2 haplotypes previously found to be globally distributed. Additionally, 1 novel haplotype was defined from western County Kerry. On-going genetic tagging will eventually provide more accurate estimates of global basking shark population structuring, abundance and behavioural ecology.
\end{abstract}

KEY WORDS: Non-invasive sampling - Mucus swabs - Basking shark - Cetorhinus maximus · Elasmobranchs $\cdot$ Genetic monitoring

\section{INTRODUCTION}

Non-invasive genetic sampling through the collection of animal-shed hair or feathers has become fundamental for genetic monitoring and conservation of vulnerable species, providing a viable and powerful alternative to blood or tissue sampling (Taberlet et al. 1997, Schwartz et al. 2007). In the marine environment, DNA has been obtained non-invasively from seal scat (Reed et al. 1997), dolphin faecal plumes (Parsons et al. 1999), cetacean blows (Frère et al. 2010) and, more recently, from water samples to detect harbour porpoises through environmental DNA (eDNA) (Foote et al. 2012). Current literature focuses mainly on the remote collection of marine mammal genetic material, with little attention paid to sampling protected elasmobranchs in a way that avoids disturbance. 
The filter-feeding basking shark Cetorhinus maximus is the world's second largest fish and is classified on the IUCN Red List as 'Vulnerable' worldwide and 'Endangered' in the Northeast Atlantic (NEA) region (www.iucnredlist.org/details/39340/0, reviewed in Sims 2008). In 2000, the basking shark was listed in Appendix III of the Convention on the International Trade in Endangered Species (CITES), and was upgraded in 2002 to CITES Appendix II, which requires monitoring through licences to ensure that trade can be sustained without detriment to wild populations. Currently, it is one of only 8 sharks with protective legislation of this type. Although circumglobally distributed, the western European shelf provides a key habitat, with persistent seasonal aggregations or 'hotspots' in areas of higher zooplankton abundance closely associated with frontal areas around SW England, NW Scotland, Ireland and the Isle of Man (Berrow \& Heardman 1994, Sims \& Quayle 1998, Sims et al. 2000, Southall et al. 2005, Witt et al. 2012). Satellite tracking has revealed that basking sharks in the NEA overwinter on the continental shelf and shelf edge in deeper waters and frequent stratified coastal waters mainly during summer (Southall et al. 2006). They are capable of trans-equatorial and transoceanic movements (Gore et al. 2008, Skomal et al. 2009), thereby demonstrating potential for long-distance dispersal. The little biological data available and preliminary mitochondrial DNA (mtDNA) analyses suggest that basking shark global population structure is panmictic, exhibiting low worldwide genetic variability with no differentiation between ocean basins (Hoelzel et al. 2006). However, previous genetic studies have been constrained, relying on low numbers of tissue samples opportunistically collected from infrequent strandings or by-catch. To reveal basking shark social structure during aggregations and investigate potential seasonal site-fidelity, successful genetic tagging relies on rapidly sampling multiple individuals within a shoal at spatially and temporally independent hotspots. As relatively little is known about basking shark life-history strategies (Sims 2008) such a sampling design could enhance detection of consistent patterns of genetic differentiation (Waples 1998).

Genetic tagging can provide a powerful tool, revealing contemporary patterns of gene flow, population size and mating strategies in marine animals (Palsbøll 1999). Conventional tags or natural marks can be lost or can change over time, whereas a genetic signature allows for $100 \%$ tag retention and significantly reduces the cost and time associated with studying highly vagile species (Andreou et al.
2012). However, traditional sampling techniques such as skin biopsies or fin clips are more difficult in the protected basking shark: not only do they require expensive equipment and highly specialized tagging skills that require official licences, but they are also less successful due to the hard skin of Cetorhinus maximus. This has potential to induce disturbance of an individual's behaviour within an aggregation, making mucus collection the preferred option for legislative bodies charged with protection and licensing of work on threatened species.

A non-destructive genetic sampling procedure using body mucus placed on FTA ${ }^{\circledR}$ cards (reagentloaded papers) has been described from laboratorykept teleost fish (Livia et al. 2006), and validated in a protocol designed to investigate contamination risks associated with high-density groups of small cichlids (Le Vin et al. 2011). Hoolihan et al. (2009) were able to modify this method for live-caught teleosts. Here, going beyond laboratory conditions, we demonstrate the feasibility of collecting skin mucus swabs from free-ranging elasmobranchs. Basking sharks naturally secrete a thick mucus (slime) covering their entire skin surface (Matthews \& Parker 1950), which has been suggested as a potential DNA source (Sims 2008), but has yet to be tested.

In this study, we report the first successful attempt to collect elasmobranch mucus in the field and its efficacy for genetic analyses. We demonstrate the potential of mucus swabs as a vehicle for large-scale population genetic monitoring of basking sharks, an approach which may be applicable to other protected sharks, skates and rays where there is a need to assess changes in population dynamics and identify ecologically important sites. Here we test the utility of basking shark mucus swabs using 2 maternally inherited mtDNA genes (cytochrome $c$ oxidase subunit I [COI] and the control region [CR]), and the nuclear ribosomal internal transcribed spacer 2 (ITS2) region sequences. Mucus swabbing proved to be a simple, reliable, relatively non-invasive method, requiring minimal training to obtain samples yielding good-quality DNA from the target species, with the benefits of reduced costs, time and disturbance associated with sampling vulnerable sharks.

\section{MATERIALS AND METHODS}

\section{Sample locality and collection}

Mucus samples were collected from Irish coastal waters, which, together with their continental shelves, 
present an important seasonal habitat for basking sharks in the NEA (Berrow \& Heardman 1994). Mucus was first obtained in 2008 during a basking shark tagging study in County (Co.) Donegal, Ireland, when a shark struck the side of a boat with its tail after being tagged, leaving behind a sample of black slime. This was removed from the boat's bow, stored in $70 \%$ ethanol, and genomic DNA was successfully extracted. This formed the basis for development of a sampling methodology as follows. Upon detection of a basking shark at the surface, the shark was approached slowly from the side. The sampling device involved a mop handle and an extendable pole with a coarse pan scourer or a cotton cloth attached by cable ties to the handle (Berrow \& Johnston 2009; our Fig. 1). Skin mucus swabs were collected by gently rubbing the scourer/cloth along the shark's dorsal side, from front to back, or its dorsal fin. There was no risk of breaking the skin, as only surface mucus was recovered. The scourer/cloth was removed and easily replaced for the next sampling attempt. Small amounts of mucus were needed for genetic analysis, and 1 stroke per shark proved to be sufficient. Samples were stored in $99 \%$ ethanol at $4^{\circ} \mathrm{C}$. A total of 30 mucus samples were collected between 20 May and 14 July 2010 off Co. Donegal (n $=19)$, Co. Cork $(\mathrm{n}=5)$, and Co. Kerry $(\mathrm{n}=6)$, Ireland (Fig. 2). No reaction to the sampling procedure was recorded for most sharks, whilst some exhibited a mild reaction best described as a 'startle' response, thought to be due to the close proximity of the boat and touching the shark with the pole, rather than discomfort associated with the sampling attempt. Depending on the county in which they were sampled, differently coloured conventional number tags were deployed for mark-recapture. Simultaneous tagging ensured that individuals were not resampled. Size and sex were assessed, when possible, using a pole-mounted camera, and geographic location was recorded by an onboard global positioning system (GPS). Additionally, 2 basking shark tissue samples were obtained from incidental by-catch one off Co. Donegal and one off Co. Dublin.

\section{DNA extraction, amplification and quantification}

Mucus was taken directly from the scourer or, alternatively, a $1 \mathrm{~cm}^{2}$ piece of mucus-covered cloth was used for DNA extraction. Total genomic DNA was extracted from 30 mucus samples and 2 by-catch tissue samples using either the Qiagen ${ }^{\circledR}$ DNeasy tissue kit or proteinase K digestion and standard phenol-chloroform procedures (Sambrook et al. 1989).

A $652 \mathrm{bp}$ fragment from the 5' region of the mtDNA COI gene was amplified for DNA barcoding (Hebert et al. 2003) using the FishF2 and FishR2 primers from Ward et al. (2005). PCRs were performed in a Biometra T-Gradient thermocycler consisting of an initial denaturation step of $95^{\circ} \mathrm{C}$ for $5 \mathrm{~min}$, followed by 35 cycles of $45 \mathrm{~s}$ at $94^{\circ} \mathrm{C}, 60 \mathrm{~s}$ at $50^{\circ} \mathrm{C}, 60 \mathrm{~s}$ at $72^{\circ} \mathrm{C}$, and a final extension phase of $10 \mathrm{~min}$ at $72^{\circ} \mathrm{C}$. The
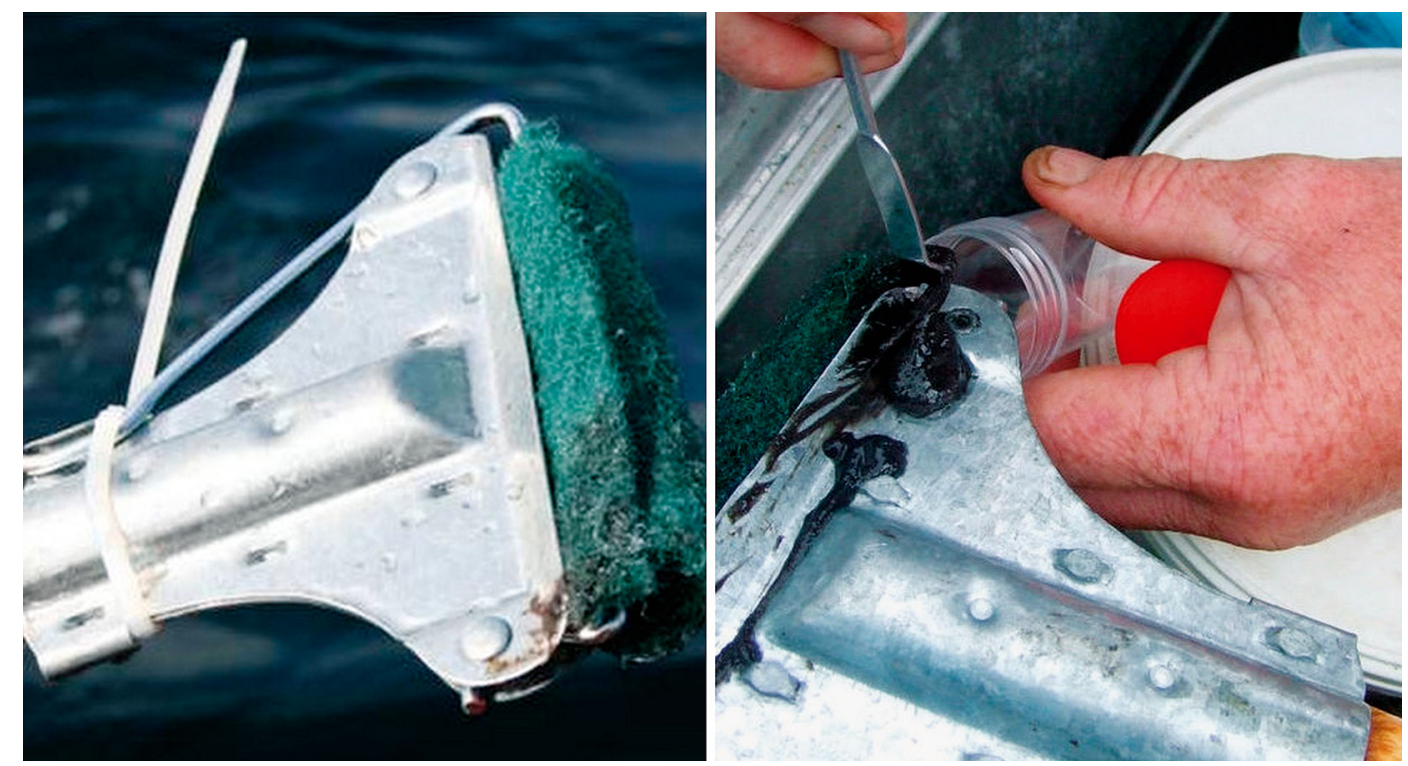

Fig. 1. Sampling procedure, using scouring pads (showing black mucus) attached to an extendable pole by cable ties to obtain mucus from basking sharks Cetorhinus maximus (Berrow \& Johnston 2009) 


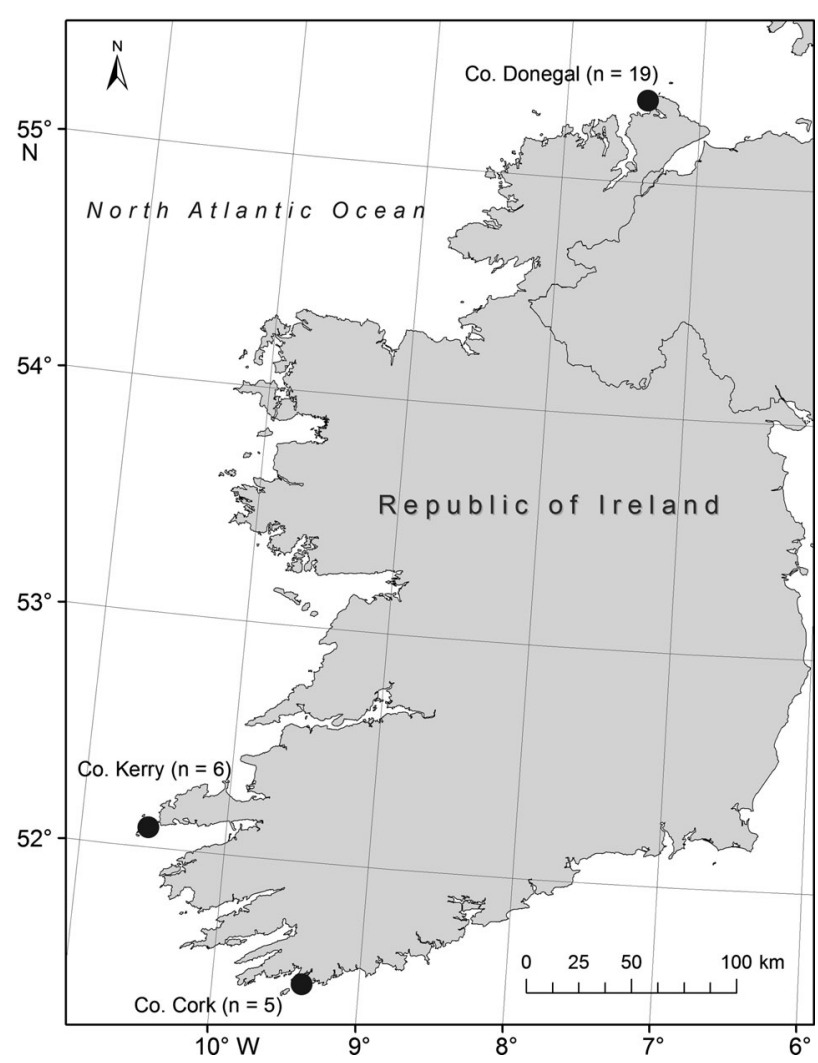

Fig. 2. Cetorhinus maximus. Locations for collection of mucus samples from basking sharks between 20 May and 14 July 2010

$40 \mu \mathrm{l}$ reaction mix contained $1 \times$ PCR buffer, $200 \mu \mathrm{M}$ deoxynucleotide triphosphates dNTPs, $1.5 \mathrm{mM}$ $\mathrm{MgCl}_{2}, 0.3 \mu \mathrm{M}$ of each primer, $0.5 \mathrm{U}$ of Taq DNA polymerase (Bioline) and $10 \mathrm{ng}$ genomic DNA. PCR products from 8 mucus samples and 1 Cetorhinus maximus tissue sample (control) were visualized on a $1 \%$ agarose gel, purified (QIAquick PCR purification kits, Qiagen ${ }^{\circledR}$ ) and bidirectionally sequenced (Beckman Coulter Genomics). A sequence similarity search was performed in GenBank using the BLAST algorithm.

PCR amplifications to recover the full mtDNA CR (1086 bp) used primers CMARH-F and CMARH-R (Hoelzel et al. 2006) in $40 \mu \mathrm{l}$ mixtures consisting of $1 \times$ PCR buffer (Bioline), $200 \mu \mathrm{M}$ dNTPs, $1 \mathrm{mM} \mathrm{MgCl}_{2}$, $0.2 \mu \mathrm{M}$ of each primer, $0.4 \mathrm{U}$ Taq DNA polymerase (Bioline) and $2.5 \mu \mathrm{l}$ genomic DNA template. Cycling conditions consisted of an initial 5 min denaturation at $95^{\circ} \mathrm{C}$, followed by 35 cycles of $45 \mathrm{~s}$ at $94^{\circ} \mathrm{C}, 1 \mathrm{~min}$ $30 \mathrm{~s}$ at $55^{\circ} \mathrm{C}, 1 \mathrm{~min} 30 \mathrm{~s}$ at $72^{\circ} \mathrm{C}$, and a final extension phase of $8 \mathrm{~min}$ at $72^{\circ} \mathrm{C}$. One positive control (tissue sample) and 1 negative control were used during each set of PCRs to assess band size and contamina- tion. A total of 12 samples failed to amplify and, therefore, 2 internal, CMARH-F1 and CMARH-R2 primers were used (Hoelzel et al. 2006), which involved performing 2 additional and separate PCRs (CMARH-F \& CMARH-R2 550 bp and CMARH-F1 \& CMARH-R $\sim 1000 \mathrm{bp}$ ) to give a final composite sequence of $1086 \mathrm{bp}$. PCR amplifications were performed in a $30 \mu \mathrm{l}$ reaction mix consisting of $20 \mathrm{ng}$ DNA, $1 \times$ PCR buffer (Bioline), $200 \mu \mathrm{M}$ dNTPs, $0.3 \mu \mathrm{M}$ of each primer, $1 \mathrm{mM} \mathrm{MgCl} 2$ and $0.7 \mathrm{U}$ Taq DNA polymerase (Bioline). PCR conditions were as described above; however, the annealing temperature was $56.7^{\circ} \mathrm{C}$ for CMARH-F-R2 and $46.8^{\circ} \mathrm{C}$ for CMARH-F1-R. All 32 amplified products were purified using QIAquick PCR purification kits (Qiagen ${ }^{\circledR}$ ) and bidirectionally sequenced (Beckman Coulter Genomics). Samples showing new haplotypes were re-amplified and sequenced to verify polymorphisms (nomenclature as in Hoelzel et al. 2006).

Mucus samples were amplified in a multiplex PCR with shark ITS universal primers FISH5.8SF and FISH28SR (Pank et al. 2001), and 2 internal basking shark-specific primers BSK328F and BSK503F using 20 to $200 \mathrm{ng}$ DNA template following Magnussen et al (2007), with a negative and 2 positive controls (Irish and New Zealand tissue samples). A subset of 9 mucus samples and the 2 positive controls were amplified with the ITS2 FISH5.8SF and FISH28SR primers to produce a $1400 \mathrm{bp}$ amplicon, and were gel-extracted using QIAquick gel extraction kit (Qiagen ${ }^{\circledR}$ ). All 11 samples were bidirectionally sequenced to give $486 \mathrm{bp}$ partial 5.8S rDNA-ITS2 region sequences for direct comparison with those in GenBank (Magnussen et al. 2007).

\section{Sequence analyses}

Sequences were edited using Proseq V.3.0 and aligned in Clustal X V.1.8.3 (Thompson et al. 1997) using default parameter settings. A neighbour-joining tree was constructed using mtDNA COI sequences in MEGA V.5.03 (Tamura et al. 2011) using the Kimura 2-parameter (K2P) model (Kimura 1980), with 10000 bootstrap replicates; 2 great white shark Carcharodon carcharias sequences were used as an outgroup (Wong et al. 2009). DnaSP V.4.5.0 (Librado \& Rozas $2009)$ was used to estimate nucleotide diversity $(\pi)$, haplotype diversity $(h)$, and for detection of polymorphic sites for both mtDNA COI and CR sequences. A haplotype network for the mtDNA CR region was constructed using the median-joining (MJ) algorithm in Network V.4.5.1 (Bandelt et al. 1999). 


\section{RESULTS AND DISCUSSION}

To confirm the presence of Cetorhinus maximus genomic DNA, 8 mucus samples (from the 3 different sites; Fig 2) and 1 tissue sample were selected for barcoding using mtDNA COI gene sequences, with BLAST searches returning 99 to $100 \%$ sequence identity with $C$. maximus for all samples. In addition, sequences were pasted into the BOLD (Barcode of Life Data system) (www.barcodinglife.com/index. php/IDS_OpenIdEngine) search engine, again verifying $100 \%$ matches to $C$. maximus. Aligning the 9 Irish COI sequences with 44 global C. maximus COI sequences available in GenBank revealed 6 polymorphic sites defining 5 COI haplotypes $(h=0.528 \pm$ $0.069 \mathrm{SD}, \pi=0.00176 \pm 0.00032 \mathrm{SD}$ ) which show a worldwide distribution. The Irish samples showed 2 of the 5 haplotypes reported in Wong et al. (2009) (our Fig. 3); Hap_2 was found in Co. Donegal $(\mathrm{n}=1)$ and Co. Kerry $(\mathrm{n}=2)$ samples, while Hap_4 was found in all 3 Irish samples (Co. Donegal, $n=3$; Co. Kerry, $\mathrm{n}=1$; Co. Cork, $\mathrm{n}=2$ ).

Twenty-three mucus samples and 1 by-catch tissue sample from Ireland were successfully sequenced for the mtDNA CR. These samples were dominated by 2 haplotypes (BS1 and BS2; the tissue sample displayed BS2), in common with those from other ocean basins and exhibited extremely low nucleotide and moderate haplotype diversity $(h=0.533 \pm 0.105$, $\pi=0.00069 \pm 0.00021)$, concordant with Hoelzel et al. (2006) (our Table 1, Fig. 4). However, 1 new haplotype (BS7) was defined from a single Co. Kerry individual (Table 1).

All 11 Irish 486 bp 5.8S rDNA-ITS2 region sequences were identical to the 10 globally distributed reference basking sharks (GenBank accession no. EF194106) from Magnussen et al. (2007), confirming nuclear DNA can be amplified and sequenced from mucus samples. Similarly, both sets of primers for multiplex PCRs consistently produced speciesdiagnostic amplicons from the mucus samples.

Findings from both mtDNA gene regions and the ITS2 sequences suggest little global population structure and low genetic variability. High rates of gene flow are characteristic of large, highly mobile elasmobranchs, especially from areas lacking any apparent physical barriers to movement.

This study reports the utility and first successful field collection of mucus samples for population genetic analysis of an endangered shark species. Rather than relying on samples collected opportunistically, and in accordance with current conservation practices, we demonstrate the utility of mucus samples as a non-invasive and rapid technique to obtain genetic samples from multiple geographic hotspots for this species within 1 season.

To the best of our knowledge, the sampling technique described here provides the least harmful and, simultaneously, the most cost- and resource-efficient way of collecting samples from some elasmobranchs. Mucus glands are numerous and common in fish skin (Shephard 1994), so collection of mucus swabs should be considered for other vulnerable elasmobranch species, such as the whale shark Rhincodon typus or the manta ray Manta birostris, species that spend time either at or near the surface, and are slow moving or approachable by divers. Taberlet et al. (1999) argued that the term 'non-invasive sampling' should be restricted to DNA material taken from what is 'left behind' by an animal. Therefore, our

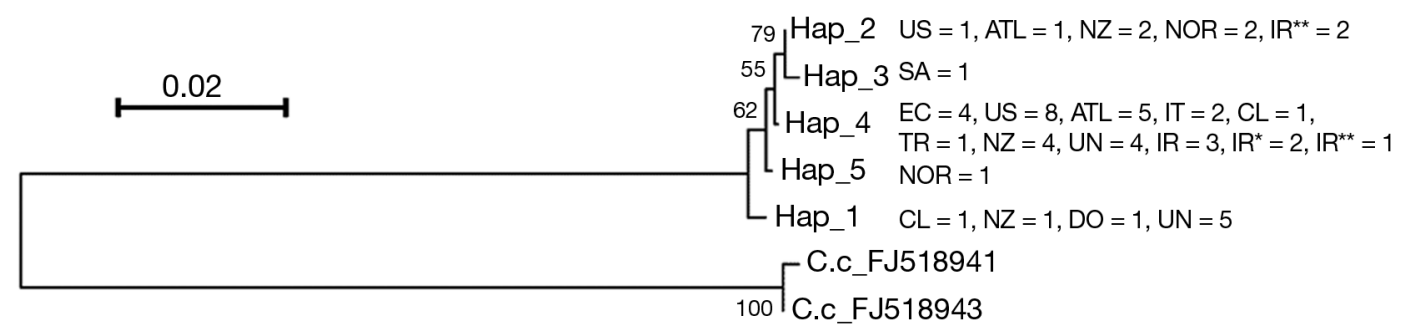

Fig. 3. Cetorhinus maximus. Neighbour-joining tree of 53 global basking shark mitochondrial DNA cytochrome $c$ oxidase subunit I (COI) sequences (652 bp). Two great white shark Carcharodon carcharias (C.c.) COI sequences were used as an outgroup. The values displayed are bootstrap support values (only $>50 \%$ are shown) derived from 10000 iterations using the Kimura 2-parameter model. Two haplotypes are found in the Irish basking shark samples (Hap_2 and Hap_4). Haplotype 4 seems to be the most common haplotype worldwide. Regions are ATL: Atlantic; CL: Chile; DO: Dominican Republic; EC: Ecuador; IT: Italy; NOR: Norway; NZ: New Zealand; SA: South Africa; TR: Turkey; UN: unknown; US: United States of America; and IR (Ireland), Co. Donegal; IR*: Co. Cork; IR**: Co. Kerry. The by-catch tissue sample from north of Co. Donegal is included within IR. All COI sequences were taken from Wong et al. (2009), except for accession nos. GU805881 (origin: Italy) (submitted 2010 to the EMBL/GenBank/DDBJ databases) and HQ167642 (origin: Turkey) (E. Keskin unpubl.). Scale bar: number of substitutions per site 


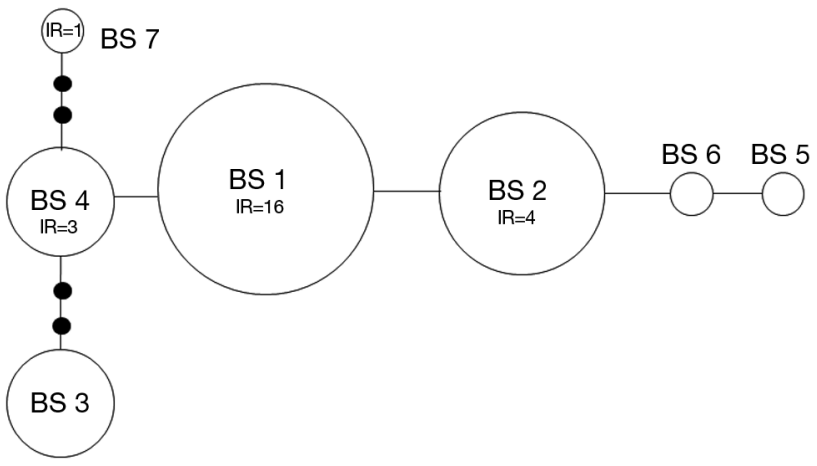

Fig. 4. Cetorhinus maximus. Statistical median-joining network of the 7 global basking shark haplotypes across various oceanic regions (NWA, NEA, MED, PAC, SA, CAR, IR, see Table 1), including 24 Irish sequences. The number of Irish (IR) individuals displaying each haplotype is indicated. The network shows evidence for global panmixia among different oceans, dominated by 2 haplotypes, BS1 and BS2. Most Irish samples from this study share BS1 ( $\mathrm{n}=16$ ); otherwise, no structure is evident among the 3 hotspots. One new haplotype from County Kerry, BS7 $(n=1)$ was defined. Single mutational steps are assumed between haplotypes unless indicated by black dots. Circle sizes are proportional to haplotype frequencies

method would not fit this strict criterion. However, here we did not break the skin and did not induce a significant, immediate behavioural response (such as displacement or deep dives), indicating that mucus sampling does not cause undue distress to individuals. Observations of sampled sharks showed that most resumed feeding on the surface $<1$ min after sampling. Consequently, we would argue that not only is our method non-destructive, but it can also be referred to as non-invasive.

Regarding the limitations of mucus swabs, there is always a risk of amplifying microbial DNA when extracting mucus samples, resulting in DNA low in target template. However, the subsequent use of species-specific markers and advances in DNA barcoding can usually overcome this issue (Holmes et al. 2009, Wong et al. 2009). Although some samples were of lower DNA quantity and quality, $>75 \%$ of the samples amplified successfully, demonstrating the utility of mucus samples for DNA extraction and sequencing. Future development will involve nuclear marker discovery, microsatellites and single nucleotide polymorphisms (SNPs), for basking shark genotyping, providing additional tools to elucidate global population connectivity. These markers hold the promise of improved genotyping from degraded DNA (Morin \& Mccarthy 2007, Helyar et al. 2011), such as that obtained with mucus swabs.

The basking shark is listed as a UK BAP (Biodiversity Action Plan) species, and research into the basking shark's population status, as well as the collection of biological material, is encouraged (JNCC 2012). At present, mucus swabs provide a viable alternative to collecting DNA invasively, and because population samples can be collected over short time periods easily, with minimal equipment and training, such collections may prove more obtainable and informative than isolated opportunistic samples. Further spatiotemporal mucus sampling of Cetorhinus maximus geographic hotspots could assist in identifying key sites and management units (Moritz 1994, Palsbøll et al. 2007), eventually allowing new insights into basking shark population dynamics and social patterning. We conclude that the ability to genotype populations from mucus fulfils several prerequisites for effective conservation management of highly mobile, marine mega-vertebrates (Morin et al. 2004).

Table 1. Cetorhinus maximus. Polymorphic nucleotide sites and defined haplotypes in mitochondrial DNA control region (1086 bp) sequences of 24 Irish basking sharks, including 6 previously defined haplotypes and frequencies from Hoelzel et al. (2006). Polymorphism position refers to the light-strand sequence along the $1086 \mathrm{bp}$ sequences from Hoelzel et al. (2006). The dash at nucleotide position 966 indicates a deletion. Hap: haplotype; dots indicate same nucleotide position as Haplotype BS1. Sampling areas are NWA: Northwest Atlantic; NEA: Northeast Atlantic; MED: Mediterranean; PAC: Pacific Ocean; SA: South Africa; CAR: Caribbean. Mucus samples from Ireland are IR (Ireland), Co. Donegal; IR*: Co. Cork; IR**: Co. Kerry. The bycatch tissue sample from north of Co. Donegal is included within IR. Dashes under 'Sampling area and haplotype frequency' indicate absence of a haplotype in a sampling area

\begin{tabular}{|c|c|c|c|c|c|c|c|c|c|c|c|c|c|c|c|c|}
\hline \multirow[t]{2}{*}{ Нар } & \multicolumn{7}{|c|}{-Polymorphism position } & \multicolumn{9}{|c|}{ - Sampling area and haplotype frequency } \\
\hline & 182 & 450 & 639 & 794 & 877 & 887 & 966 & NWA & NEA & MED & PAC & $\mathrm{SA}$ & CAR & IR & $\mathrm{IR}^{*}$ & $\mathrm{IR}^{* *}$ \\
\hline BS1 & $\mathrm{T}$ & A & G & G & $\mathrm{C}$ & $\mathrm{C}$ & - & 5 & 3 & - & 13 & - & - & 12 & 2 & 2 \\
\hline BS2 & . & . & . & A & . & . & . & 6 & 2 & 4 & 10 & - & - & 2 & 2 & - \\
\hline BS3 & $\mathrm{C}$ & $\mathrm{G}$ & A & . & . & . & . & 3 & 1 & - & 5 & - & 1 & - & - & - \\
\hline BS4 & $\mathrm{C}$ & . & . & . & . & . & . & 1 & 1 & - & 4 & 1 & - & 2 & - & 1 \\
\hline BS5 & C & . & . & A & . & . & A & - & - & - & 1 & - & - & - & - & - \\
\hline BS6 & . & . & . & A & . & . & A & - & - & - & 1 & - & - & - & - & - \\
\hline BS7 & . & . & . & . & $\mathrm{T}$ & $\mathrm{T}$ & . & - & - & - & - & - & - & - & - & 1 \\
\hline
\end{tabular}


Acknowledgements. The fieldwork for this study in Ireland was funded by a Heritage Council Wildlife Grant (Grant Reference 16759). This work received funding from the MASTS pooling initiative (The Marine Alliance for Science and Technology for Scotland) and their support is gratefully acknowledged. MASTS is funded by the Scottish Funding Council (grant reference HR09011) and contributing institutions. Thanks to Margaret Wallace for technical support, and Michaél Cottrell, Darren Craig, Laura Kavanagh, Lucy Hunt, Nick Massett and Ian O'Connor for help with fieldwork and sample collection.

\section{LITERATURE CITED}

Andreou D, Vacquie-Garcia J, Cucherousset J, Blanchet S, Gozlan RE, Loot G (2012) Individual genetic tagging for teleosts: an empirical validation and a guideline for ecologists. J Fish Biol 80:181-194

Bandelt HJ, Forster P, Röhl A (1999) Median-joining networks for inferring intraspecific phylogenies. Mol Biol Evol 16:37-48

Berrow SD, Heardman C (1994) The distribution and abundance of basking sharks Cetorhinus maximus (Gunnerus) in Irish waters. Biol Environ Proc R Ir Acad B 94: 101-107

Berrow S, Johnston E (2009) Basking shark survey: tagging and tracking. Final Report for the Heritage Council, Wildlife Grant R16759, www.baskingshark.ie/downloads/ basking_shark_final_report_heritage_council.pdf

Foote AD, Thomsen PF, Sveegaard S, Wahlberg M and others (2012) Investigating the potential use of environmental DNA (eDNA) for genetic monitoring of marine mammals. PLoS One 7:e41781

Frère CH, Krzyszczyk E, Patterson EM, Hunter S, Ginsburg A, Mann J (2010) Thar she blows! A novel method for DNA collection from cetacean blow. PLoS ONE 5: e12299

Gore MA, Rowat D, Hall J, Gell FR, Ormond RF (2008) Transatlantic migration and deep mid-ocean diving by basking shark. Biol Lett 4:395-398

Hebert PDN, Ratnasingham S, DeWaard JR (2003) Barcoding animal life: cytochrome $c$ oxidase subunit 1 divergences among closely related species. Biol Lett 270 (Suppl):96-99

> Helyar SJ, Bekkevold D, Taylor MI, Ogden R, Limborg MT (2011) Application of SNPs for population genetics of nonmodel organisms: new opportunities and challenges. Mol Ecol Resour 11:123-136

> Hoelzel AR, Shivji MS, Magnussen J, Francis MP (2006) Low worldwide genetic diversity in the basking shark (Cetorhinus maximus). Biol Lett 2:639-642

$>$ Holmes BH, Steinke D, Ward RD (2009) Identification of shark and ray fins using DNA barcoding. Fish Res 95: 280-288

Hoolihan JP, Perez NF, Faugue RM, Bernard AM, Horn RL, Snodgrass D, Schultz DR (2009) Surface mucous as a source of genomic DNA from Atlantic billfishes (Istiophoridae) and swordfish (Xiphiidae). Fish Bull 107: 339-342

JNCC (Joint Nature Conservation Committee) (2012) UK priority species data collation Cetorhinus maximus, Version 2, updated on 15/12/2010. http://jncc.defra.gov.uk/ _speciespages/203.pdf (accessed 6 November 2012)

Kimura M (1980) A simple method for estimating evolution- ary rates of base substitutions through comparative studies of nucleotide sequences. J Mol Evol 16:111-120

Le Vin AL, Adam A, Tedder A, Arnold KE, Mable BK (2011) Validation of swabs as a non-destructive and relatively non-invasive DNA sampling method in fish. Mol Ecol Resour 11:107-109

> Librado P, Rozas J (2009) DnaSP v5: a software for comprehensive analysis of DNA polymorphism data. Bioinformatics 25:1451-1452

> Livia L, Antonella P, Hovirag L, Mauro N, Panara F (2006) A nondestructive, rapid, reliable and inexpensive method to sample, store and extract high-quality DNA from fish body mucus and buccal cells. Mol Ecol Notes 6:257-260

> Magnussen JE, Pikitch EK, Clarke SC, Nicholson C, Hoelzel AR, Shivji MS (2007) Genetic tracking of basking shark products in international trade. Anim Conserv 10: 199-207

Matthews LH, Parker HW (1950) Notes on the anatomy and biology of the basking shark Cetorhinus maximus (Gunner). Proc Zool Soc Lond 120:535-576

Morin PA, Mccarthy M (2007) Highly accurate SNP genotyping from historical and low-quality samples. Mol Ecol Notes 7:937-946

Morin PA, Luikart G, Wayne RK (2004) SNPs in ecology, evolution and conservation. Trends Ecol Evol 19:208-216

Moritz C (1994) Defining 'Evolutionarily Significant Units' for conservation. Trends Ecol Evol 9:373-375

> Palsbøll P (1999) Genetic tagging: contemporary molecular ecology. Biol J Linn Soc 68:3-22

> Palsbøll PJ, Bérubé M, Allendorf FW (2007) Identification of management units using population genetic data. Trends Ecol Evol 22:11-16

> Pank M, Stanhope M, Natanson L, Kohler N, Shivji M (2001) Rapid and simultaneous identification of body parts from the morphologically similar sharks Carcharhinus obscurus and Carcharhinus plumbeus (Carcharhinidae) using multiplex PCR. Mar Biotechnol (NY) 3:231-240

> Parsons KM, Dallas JF, Claridge DE, Durban JW, Balcomb KC, Thompson PM, Noble LR (1999) Amplifying dolphin mitochondrial DNA from faecal plumes. Mol Ecol 8: 1766-1768

Reed JZ, Tollit DJ, Thompson PM, Amos W (1997) Molecular scatology: the use of molecular genetic analysis to assign species, sex and individual identity to seal faeces. Mol Ecol 6:225-234

Sambrook J, Fritsch EF, Maniatis T (1989) Molecular cloning: a laboratory manual, 2nd edn. Cold Spring Harbor Laboratory Press, New York, NY

Schwartz MK, Luikart G, Waples RS (2007) Genetic monitoring as a promising tool for conservation and management. Trends Ecol Evol 22:25-33

Shephard K (1994) Functions for fish mucus. Rev Fish Biol Fish 4:401-429

Sims DW (2008) Sieving a living: a review of the biology, ecology and conservation status of the plankton-feeding basking shark Cetorhinus maximus. Adv Mar Biol 54: 171-220

Sims DW, Quayle VA (1998) Selective foraging behaviour of basking sharks on zooplankton in a small-scale front. Nature 393:460-464

Sims DW, Southall EJ, Quayle VA, Fox AM (2000) Annual social behaviour of basking sharks associated with coastal front areas. Proc Biol Sci 267:1897-1904

Skomal GB, Zeeman SI, Chisholm JH, Summers EL, Walsh HJ, McMahon KW, Thorrold SR (2009) Transequatorial 
migrations by basking sharks in the western Atlantic Ocean. Curr Biol 19:1019-1022

Southall EJ, Sims DW, Metcalfe JD, Doyle JI and others (2005) Spatial distribution patterns of basking sharks on the European shelf: preliminary comparison of satellitetag geolocation, survey and public sightings data. J Mar Biol Assoc UK 85:1083-1088

Southall EJ, Sims DW, Witt MJ, Metcalfe JD (2006) Seasonal space-use estimates of basking sharks in relation to protection and political-economic zones in the north-east Atlantic. Biol Conserv 132:33-39

Taberlet P, Camarra JJ, Griffin S, Uhrès E and others (1997) Noninvasive genetic tracking of the endangered Pyrenean brown bear population. Mol Ecol 6:869-876

Taberlet P, Waits L, Luikart G (1999) Non-invasive genetic sampling: look before you leap. Trends Ecol Evol 14: 323-327

Tamura K, Peterson D, Peterson N, Stecher G, Nei M, Kumar S (2011) MEGA5: molecular evolutionary genetics analysis using maximum likelihood, evolutionary distance,

Editorial responsibility: Mike Bruford,

Cardiff, UK and maximum parsimony methods. Mol Biol Evol 28: 2731-2739

Thompson JD, Gibson TJ, Plewniak F, Jeanmougin F, Higgins DG (1997) The CLUSTAL_X windows interface: flexible strategies for multiple sequence alignment aided by quality analysis tools. Nucleic Acids Res 25: 4876-4882

Waples RS (1998) Patterns of genetic differentiation in high gene flow species. J Hered 89:438-450

Ward RD, Zemlak TS, Innes BH, Last PR, Hebert PDN (2005) DNA barcoding Australia's fish species. Philos Trans R Soc Lond B Biol Sci 360:1847-1857

> Witt M, Hardy T, Johnson L, McClellan C and others (2012) Basking sharks in the northeast Atlantic: spatio-temporal trends from sightings in UK waters. Mar Ecol Prog Ser 459:121-134

> Wong EHK, Shivji MS, Hanner RH (2009) Identifying sharks with DNA barcodes: assessing the utility of a nucleotide diagnostic approach. Mol Ecol Resour 9(Suppl S1): 243-256

Submitted: December 3, 2012; Accepted: June 9, 2013 Proofs received from author(s): August 13, 2013 